Kosztopulosz Andreász - Kuruczleki Éva (szerk.) (2020): Társadalmi és gazdasági

folyamatok elemzésének kérdései a XXI. században. Szegedi Tudományegyetem

Gazdaságtudományi Kar, Szeged, https://doi.org/10.14232/tgfek21sz.12

\title{
A digitalizáció az Óperencián és az üveghegyen is túl:
}

\section{az Ipar 4.0-hoz vezető út online kurzusokon keresztül}

\author{
Majó-Petri Zoltán
}

\begin{abstract}
A felsőoktatási piacokon belül nem csak az oktatási portfólió és az intézményrendszer van mozgásban 2010 óta, de átalakulóban van a tartalom fogyasztása is. A tanteremmel és a tanári jelenléttel leirható elsődleges fogyasztási mintázatok a digitális transzformáció mentén, a tömeges személyre szabás eszközrendszerével üzemszerüen müködtethetök az online térben is: több tíz millió hallgatója van az online kurzusoknak világszerte. A cikkben egy generalista megközelités mentén azt mutatom be, hogyan alakult ki ennek platform gazdasági modellje, kik ennek legnagyobb üzleti szereplöi, milyen jellemzö volumenekkel találkozhatunk. A magyarázó változók feltárása mellett bemutatásra kerül, hogy miért lehet sikeres egy MOOC (Massive Open Online Course) alapú képzési portfólió hosszabbtávon, és milyen átmeneti hibrid megoldások állnak elöttünk annak érdekében, hogy az Ipar 4.0 megvalósitásához szükséges oktatási transzformáció mozgásba lendüljön Magyarországon is.
\end{abstract}

Kulcsszavak: e-learning; digitális transzformáció; Ipar 4.0, Massive Open Online Course (MOOC)

\section{Digitalizációs előzmények: a „digitális ikrek” megalkotása}

Az elmúlt évek konferenciáin a digitalizáció motívuma az előadások elmaradhatatlan kelléke lett, és a digitális transzformáció (digital transformation) Matt és szerzőtársai szerint az évtized egyik hívószava a szervezetek modernizálásában (Matt et al. 2015). Azonban ennek előzmény története nagyon mélyre nyúlik vissza.

A cikknek már csak terjedelmi okok miatt sem célja ennek részletes feltárása, azonban beágyazódását érdemes keretbe foglalni. Az idővonalon az MIT Media Lab megalapításához, illetve annak alapítójához nyúlik vissza. Nicolas Negroponte, a Massachusetts Institute of Technology Média Laboratóriumának alapítója, a Being Digital címü könyvében már 1995-ben arról ír, hogy ahogyan az anyagi világot atomok alkotják, ugyanígy kialakítható körülöttünk ennek egy tökéletes mása, egy digitális ikerpár (digital twin) bitekböl (Negroponte 1995).

A virtuális, bitekből álló világnak a megalkotása pedig az emberiség egyik legnagyobb vállalkozása lehet, ami alapvető változásokat indukál a termelésben, a gazdaságban, a kereskedelemben, a szolgáltatási szektorban, ezen keresztül pedig minden más társadalmi alrendszerben az oktatástól az egészségügyön keresztül a kultúráig. Negroponte szerint az informatikus, illetve az informatika egy támogató folyamatból ezen keresztül válik a fejlődés egyik meghatározó mozgatórugójává. Lényegében ennek mentén kerültek be az infokommunikációs és telekommunikációs cégek a világ legnagyobb vállalatai közé, és váltunk mi fogyasztók a XX. század fogyasztói társadalmának tagjai az információs társadalom platformjain (pl.: Apple, Google, Facebook, Amazon, Microsoft) felhasználóvá. 
Negroponte okfejtésének gyakorlati megvalósulását szemlélteti az alábbi ábra, ami nem más mint egy hektár termőföld digitális ikerpárja, ami egy ember nélküli, robotizált müvelés talapzata.

\section{1. ábra termőföld digitális ikerpárja}

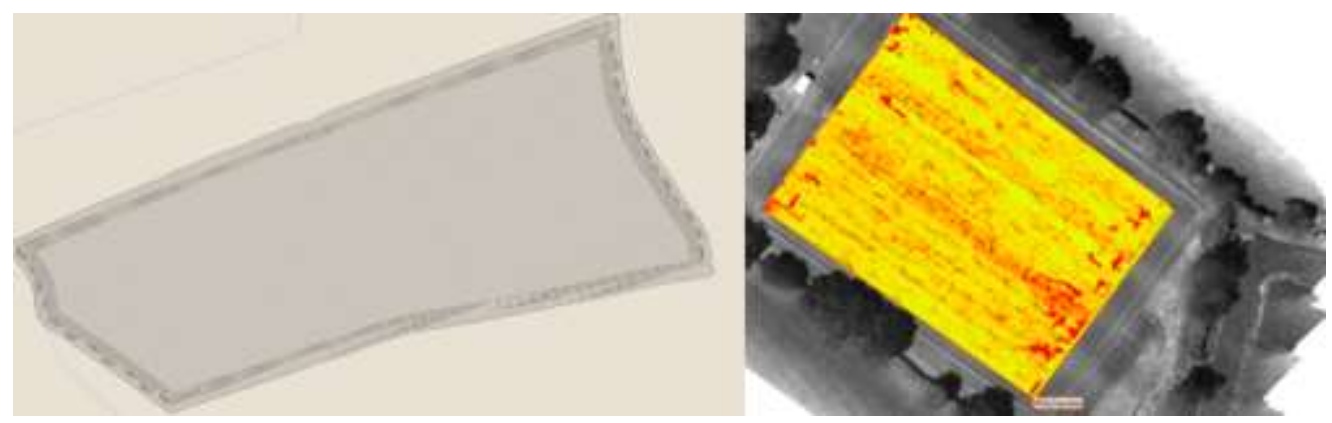

Forrás: saját szerkesztés a https://www.handsfreehectare.com/ galériája alapján

Mára ez már nem egy egyszerű digitalizált kép. A képfeldolgozás eredményeként megvalósult lenyomat, ami eredetileg egy pillanat eseményét örökíti meg, ma a terrmelés alapja: ez az első olyan angol hektár, ahol úgy termeltek egy egyetemi projektbe árpát 2016-ban, hogy a területen nem járt ember.

A mezőgazdasági termelési ciklus tele volt a múltban is automatizálási törekvésekkel, mely az emberi munka csökkentésére és kiváltására irányult, ezt jól láthatjuk évtizedek óta, sőt Rifkin „,The End of The Work” címü könyvében a mezőgazdasági munkák megszünésének külön fejezetet szentelt: bemutatva az egy hektárra eső, egy-egy munkafolyamatra jutó munkaórák számának folyamatos és radikális csökkenését (Rifkin 1995, 109. o.). Ennek elsődleges módszertana a gépesítés és az automatizáció volt, ami a digitalizációval teljesedett ki. A gépek müködtetésének és távoli irányításának utolsó elemeit már az informatikai és telekommunikációs megoldásokon keresztül fejlesztik és szállítják: így jutottunk el a Harper Adams University „emberi kéz nélküli hektár” (hands free hectare) projekthez, vagy éppen a német Osnabrück University fejlesztési projektjéhez, vagy a University of Sydney futó fejlesztéseihez. Ezek jellegzetes technológiái az IoT, a bigdata, a tanuló algoritmusok, a drón vagy éppen az önvezető jármü (King 2017). Másképpen, ahogy Martin Ford fogalmaz könyvében megjelent a precíziós mezőgazdaság, ami végleg kihúzza a talajt az olyan vizuális kihívást jelentő betakarítási tevékenységek alól is, amit eddig csak az ember volt képes megcsinálni (Ford 2017, 43. o.). Ugyan az Ipar 4.0 fogalma ma még korántsem egységes, de álláspontom szerint az Ipar 4.0 jelenségvilágát a Negroponte által modellbe foglalt, valóságot leképező bitekből álló világ digitális másolataként tekinthetjük: tekintsünk akár a nagyvállalatok ERP rendszereire, melyek digitális idegrendszerként a modern vállalat irányítás alapjai, akár az önvezető technológiákra, melyhez a jármüvek környezetének digitális mását kellett megalkotni, vagy a közösségi médiára, ami kapcsolati hálónk digitális mása. Figyeljük akár a képalkotó orvosi technológiákkal támogatott sebészrobotokat, vagy az okos városokat, ahol zöld jelzést kap a kereszteződésbe érkező villamos: érdemben 
épül világunk bitekből álló digitális ikertestvére. Megkezdődött a fizikai - biológiai társadalmi és digitális rendszerek egymásba fonódása az Ipar 4.0 eszközrendszerén keresztül: ennek a topográfiáját szemlélteti az alábbi ábra:

\section{2. ábra Technológiai egymásba fonódás 2010 után}

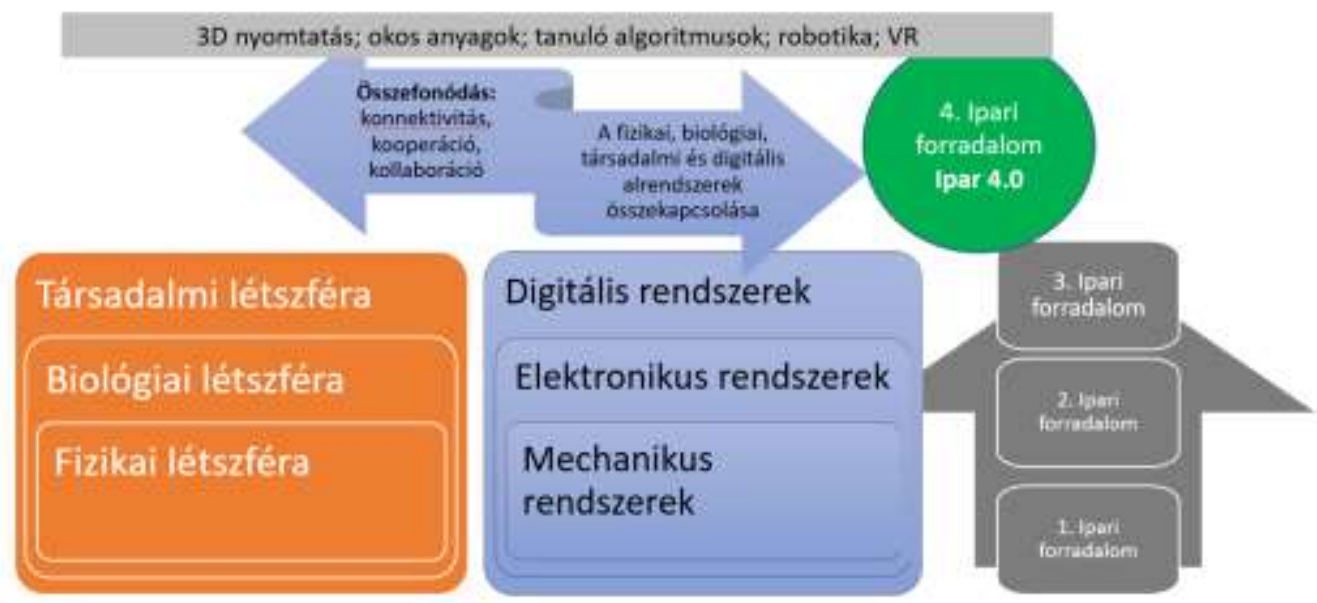

Forrás: saját szerkesztés Skilton-Hovsepian 4. Ipari forradalom hatásai alapján (SkiltonHovsepian 2018)

Ebben a szemléletben érdemesnek tartok egy felsőoktatási digitalizációs modell felépítését is megkezdeni. Ennek elsődleges mozgatórugója lehet, hogy a tanterem, ami a mechanikus korszak elismerésre méltó eredménye, mint elsődleges technológia tér átalakuljon.

\section{Távoktatási előzmények: digitális támogatás a felsőoktatásban}

A digitális transzformációt és a platform gazdaság térnyerését figyelembe véve nem csoda, hogy a felsőoktatás vezetői intézményei és kialakították a virtuális ökoszisztémájukat: az edukatico.org bejegyzése szerint 2019 évégre mintegy 50 millió felhasználója van a Coursera és az EdX online egyetemi kurzusainak. Ez a digitális transzformáció akár az angolszász, akár az ázsiai felsőoktatási piacokon kurzusok ezreivel és diákok millióival számolhat.

$\mathrm{Az}$ online kurzusoknak természetesen megvolt a történeti előzménye a felsőoktatási alrendszerben: klasszikus tantermi oktatás mellett a távoktatás (distance learning) biztosan nem az internet „bölcsőjében” született meg: Pomerol et al. 2015ben megjelent könyve szerint az audio és videó kazetták postai kiküldése, a televízió, a rádió és végül az internet egy „fejlődési lánc” része. A szerző szerint eddig minden számítógépes és infokommunikációs technológia inspirálta a különböző helyen és/vagy különböző időben történő tanulás szereplőit (Pomerol et al. 2015).

$\mathrm{Az}$ internet használatának oktatásban történő elterjedésére itthon is sok példát ismerünk: az oktatási intézmények szinte minden IKT eszközt beépítenek a 
folyamataikba, legyen szó elektronikus ellenőrzőről vagy leckekönyvről, számítógépes vizsgáról, vagy az előadások anyagainak elektronikus elérhetőségéről és a tanterembe integrált okoseszközökről. A szoftverpiaci szereplők is specializálódtak az oktatásinformatikai területekre: az üzleti megoldás szállítók külön speciális kínálatot és kedvezményes árlistát tartanak fent diákoknak, oktatási intézményeknek, ami azt mutatja, hogy érdemi együttmüködés alakult ki a szereplők között.

A kérdés napjainkban inkább úgy vetődik fel, hogy a webes és elektronikus megoldások használata összeáll-e valamilyen új minőséggé? Ahogyan az internet beépült a vállalati értékteremtő folyamatba és lett belöle e-business - ami nem egyenlő az elektronikus kereskedelemmel (e-commerce), vagy online marketinggel úgy a kérdés az oktatásban most vált igazán aktuálissá: a MOOC hosszabb távon csak egy újabb technológiai újítás - más szóval a WEB2 beépülése a távoktatási gyakorlatba - vagy egy új müködési modellt indukál, ami az oktatási intézmények értékteremtési folyamatát is átalakítja? A coursera.org ahol 2019-ben már 38 millión tanulnak felsőoktatásban „online, ingyenes, nyílt” hívószava a kurzusfelvételre csak kiváló marketing akció, vagy egy új üzleti modell része?

Ezen kérdések sürítve úgy tüntek fel a nemzetközi szakirodalomban, hogy lesz-e új csodaszer a MOOC a felsőoktatásban (Brown 2015)? Ennek magyar adaptációja is érdekes kérdéseket vet fel, tudva hogy az atipikus felsőoktatási képzési formák (esti, levelező, távoktatási) megítélése évtizedek óta foglalkoztatja a szakembereket és közvéleményt két meghatározó aspektusból is: egyrészt hogy egyáltalán lehet-e minden szakterületen digitalizálni a tantermi oktatást, különösen a manuális szakmákat. Másrészt tekinthető-e egyenértékünek az itt szerzett tudás és diploma nappali tagozaton történő oktatással?

\section{Oktatás 2010 után: a tömeges nyílt online kurzusok (MOOC) évtizede}

A fogalom mára már letisztult a nemzetközi szakirodalomban: a tömeges nyílt online kurzusok (Massive Open Online Course, továbbiakban MOOC) olyan webes kurzusok, amelyek a korlátlan részvételt és online hozzáférést biztosítanak világhálón keresztül. A kurzushoz tartozó videók, prezentációk, olvasóleckék és esettanulmányok mellett interaktív fórumok, kvízek biztosítják a felhasználóknak a tudásmegosztást, a csoportmunkát, a kommunikációt a diákok a tanárok és az oktatást segítő személyzet között.

A MOOC már 2008-ban megjelent az angolszász egyetemi gyakorlatban, de 2012-ben vált a tanulás népszerü platformjává. A platformok között piacvezető a Coursera.org, egy amerikai oktató technológiai vállalat, amely tömeges, nyílt online kurzusokat ajánl, és jelenleg 40 millió hallgatójuk van. Alapítói Andrew Ng és Daphne Koller, akik a Stanford Egyetem számítástudomány professzorai. A Coursera platformján 2019-ben már 190 egyetem müködik együtt, hogy egyetemi kurzusaikat online elérhetővé tegyék a mérnöki tudományok, a bölcsészet, az orvostudomány, a biológia, a társadalomtudományok, a matematika, a gazdaságtudományi, és számítástudományi területekről.

Amennyiben a távoktatási elméletét és gyakorlatát is figyelembe vesszük, akkor a MOOC egy aktuális és széles körben kutatott fejlesztésnek tekinthető a távoktatási témakörben is (Bozkurt et al. 2015). Ebben az iskola falain kívüli autonóm 
munkavégzésnek, az önálló tanulási stratégiának komoly hagyománya van. A MOOC-ok terjedésének sebessége 2012 és 2015 közötti években elsősorban a „nyílt és ingyenes" tényezőkön múlt: több tízezer online kurzus született, melyekhez több százezer virtuális hallgató csatlakozott. Az alábbi ábra a MOOC kurzusok globális terjedését 3. ábra mutatja.

\section{3. ábra Induló MOOC kurzusok száma 2012-2019 között}

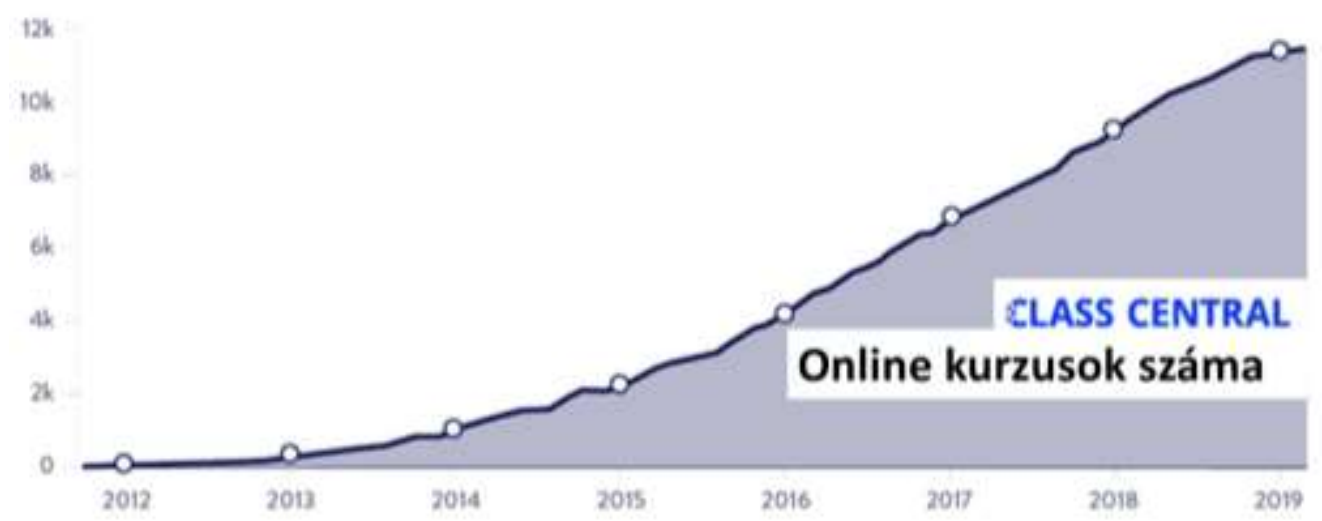

Forrás: https://www.classcentral.com/report/mooc-stats-2018/

A korai MOOC-ok gyakran hangsúlyozták a nyílt hozzáféréshez kapcsolódó jellemzőket - mint például a tartalomhoz, a struktúrához vagy a tanulási célokhoz való nyilvános hozzáférést - azzal a céllal, hogy támogassák az oktatási erőforrások ismételt felhasználását és feldolgozását. Számos később létrejött MOOC már zárt licenceket is alkalmaz az oktatási anyagokra úgy, hogy azokhoz a hallgatók ugyan ingyen hozzáférhetnek, de mindez regisztrációhoz kötött (Zemsky 2014). Zemsky szerint a MOOC már 2014-ben elérte a csúcsát: „Jöttek, hódítottak egy keveset, és most jelentősen kisebb kilátásokkal néznek szembe.” Azonban a számok mást mutatnak: az angolszász felsőoktatási környezetből kilépve, globális jelenségről beszélthetünk, melynek oka már nem az ingyenesség vagy a nyílt hozzáférés. Inkább abban keresendő, hogy egyrészt változnak fiatal generációk tanulási szokásai, attitüdjei másrészt a tanterem digitalizációja valóban sikeresebb tanulási környezetet jelent, mint a hagyományos osztályterem. Az ok is láthatóvá vált: mert szolgáltatók élni tudtak a tömeges személyre szabás lehetőségével, ami a digitális üzleti modellek alapvető müködési jellemzője.

A világ legnagyobb oktatási portálján, a Courserán 2020 elején már elérhető az első magyar nyelvü, ingyenes tanulásmódszertani kurzus is: A tanulás tanulása c. kurzus Barbara Oakley (McMaster University) és Terrence Sejnowski (University Of California San Diego) 1,9 millió hallgatóval rendelkező Learning How to Learn c. kurzusának magyar verziója. Olyan tanulási módszereket mutat be, amelyeket a müvészetek, a zene, az irodalom, a matematika, a természettudományok, a sport és más szakterületek müvelöi használnak. Az online, ingyenes tananyag a tanulás módszertanát mutatja be, és gyakorlati tanácsokat ad többek között vizsgákra való 
felkészüléssel kapcsolatban A kurzus során bemutatásra kerül, hogyan használ az emberi agy a tanuláshoz két nagyon különböző állapotot, és hogyan tudja tömbösíteni az információkat. A kurzuson résztvevők megismerhetik a kompetencia-illúziókat, a memóriatechnikákat, a halogatás kezelésének okait, egyben olyan módszereket próbálhatnak ki amivel új lendületet kaphat a tanulásban elért sikereihez, és segítenek optimalizálni a házi feladattal és a feladatmegoldással töltött időt.

\section{A tanterem és a tömeges személyre szabás hatékonysága}

Azt, hogy a tanterem a személyre szabás szempontjából nem a leghatékonyabb tudásátadó megoldás már régóta köztudott: nem véletlenül lett közismert szólásunk, hogy egy osztályteremben ,a jobbak unatkoznak, a gyengébbek pedig lemaradnak” hiszen a tanár egy ilyen környezetben átlagos sebesség mellett fog oktatni.

A tömeges személyre szabás éppen ezen a területen az egyik legnagyobb lehetőség, mert ez lehetővé teszi számunkra, hogy egy 30 éves problémát oldjunk meg. Az oktatási kutató, Benjamin Bloom 1984-ben vetette fel a 2 szigma problémát (Bloom 1984), amit három diák populáció tanulmányozásakor figyelt meg. Az első esetben a diákok előadás alapú tantermi oktatásban vettek részt. A másodikban a diákok szintén hagyományos előadás alapú tantermi oktatást használtak, de egy elsajátítás alapú megközelítést alkalmaztak, így minden egyes diák csak akkor léphetett a következő témára, amikor demonstrálta az előző anyag elsajátítását. Végül, volt egy olyan hallgatói populáció, ahol a tanár végig egyenként foglalkozott a diákokkal. A kísérletben, ahol minden tanulóval egyesével foglalkoztak, angolul „one to one tutoring”-nak nevezték el. Bloom arra jutott, ha minden tanulóval egyesével foglalkozunk, akkor a klasszikus tantermi teljesítményeket megtestesítő haranggörbe (normál eloszlás függvény) megváltozik. Eredeti cikkében mindezt az alábbi görbék szemléltették:

4. ábra Eredmények változása one-to-one tutoring esetén

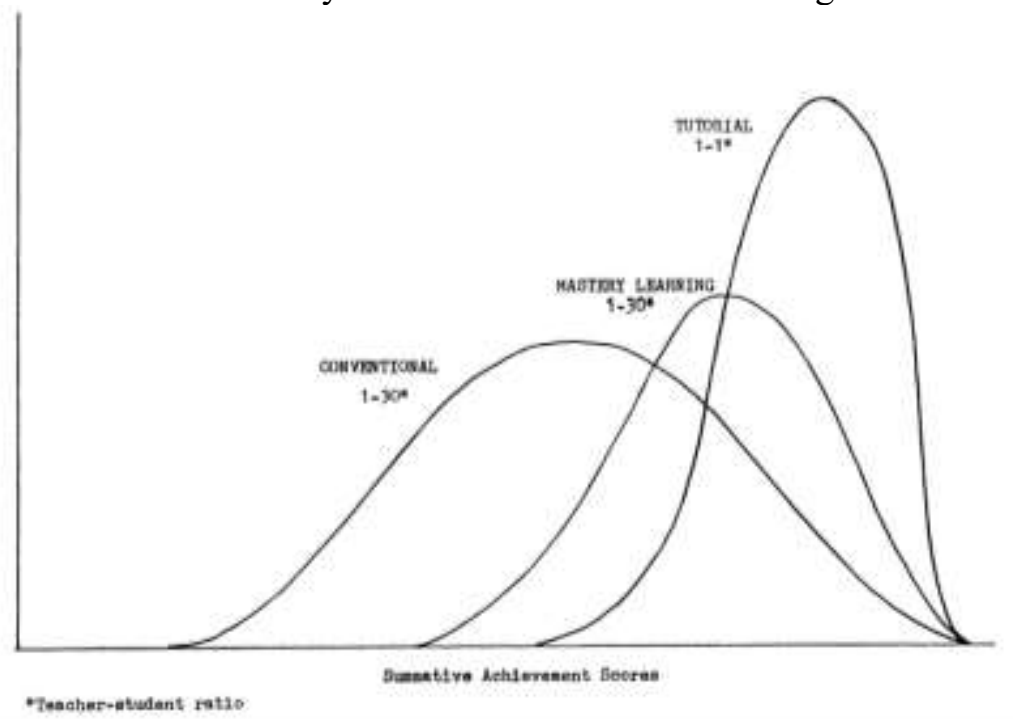

Forrás: S. Bloom: The 2 sigma problem; Educational Researcher 
Tehát ha mindenkivel tudunk egyesével foglalkozni, akkor a görbe megváltozik: a diákok akár $80 \%$ eljuthat a kiválósági tartományba harmadik görbe szerint. Másképp fogalmazva egy osztály iskolai osztályzatainak normál eloszlása (első görbe), nem elsősorban a diákokról szól, hanem a tanulási környezetről. Mindez a szakirodalomban kétszigma problémaként terjedt el. Bloom cikke után természetesen mindenki azon kezdett el dolgozni, hogyan lehet „még több” iskolát csinálni, még többet foglalkozni a diákokkal, és megtörni az eleve elrendelt „,a gyengék, közepesek és kiválóak" kategóriákat? Erre két megoldás létezett a XX. században: az egyik amikor erre az iskola volt képes, a másik amikor ezt a szülők vállalják.

Az oktatáskutatók által jól körüljárt téma közgazdász szemüvegen keresztül is vizsgálható. Az osztályterem, tanár, iskola intézményi modellje jól skálázható, ennek müködtetéséhez, fenntartásához szükséges források jól algoritmizálhatók. A kisebb osztálylétszám, több termet, több tanárt kíván: az egyéni foglalkozáshoz vezető út költségei meredeken emelkednek. Emellett szinte minden szülőben, mint vevőben megjelenik az az elvárás, hogy gyermekével lehetőség szerint egyénileg foglalkozzanak, legyen meg a lehetősége az egyénre szabásnak. Ezt szolgálják a különórák, a korrepetációk, és a fakultációk ami a szülők döntésén múlt.

A felsőoktatás digitalizációja a MOOC típusú kurzusokon keresztül állításunk szerint a tömeges személyre szabás lehetőségét teremti meg. A totális személyre szabás kulcsa pont a digitális transzformáció, azaz, hogy az oktatási folyamatban mindenkivel egyesével foglalkozhassunk: ez az Oktatás 4.0-ja az Ipar 4.0-hoz hasonlatosan, egyben Bloom 2 szigma problémájának feloldása.

Egy videóleckéket újra és újra meg lehet nézni, a kvízeket, teszteket újra és újra meg lehet csinálni, a virtuális asszisztensek fáradhatatlanul segíthetnek megoldani a feladatokat és kijavítják a dolgozatokat anélkül, hogy újra és újra megkérjük tanárainkat, fáradjanak vissza a diákokkal a tanterembe, vagy javítsák ki a dolgozatokat.

A tömeges nyílt online kurzusok folyamatos terjedésének és növekedésének pont ez az alapvető mozgató rugója: ezen a piacon számos szervezet (például egyetem, intézet vagy akár üzleti vállalkozás) indult el, a főbb szolgáltatók (platformok) mára letisztult képet mutatnak: a felhasználók számát alapul véve a Coursera, az Edx, a XuetangX a Udacity és FutureLearn emelhető ki. Az első három 10 milliós nagyságrendü felhasználói közösséget épített ki az elmúlt években. Tudva, hogy 2016-ban az Európai Unióban 19,6 millió diák tanult a felsőoktatásban a Courseranak ugyanebben az évben már 23 millió, 2018-ban pedig 38 millió felhasználója volt, nem kérdés hol van manapság expanzív növekedés.

\section{Hibrid oktatási portfóliók megjelenése}

A kérdés, miszerint a digitalizáció hatására jön-e a felsőoktatásban új müködési modell álláspontom szerint lényegében eldőlt. A tömeges személyre szabás üzemszerűen működtethető. A legtöbb MOOC alkalmaz videó felvételeket oktatásban, sokszor tantermi előadásokat, klasszikus oktatási gyakorlatokat digitalizálnak (Yousef et al. 2014). Sokan tekintik a videókat és egyéb MOOC által előállított tartalmakat a tankönyvek következő formájának, nem ritka a MOOC az új 
tankönyv kifejezés (Young 2013). Egy edX hallgatókról szóló kutatása alapján az is megállapítható, hogy a hallgatók figyelme nem tartható fent hosszabb távon sem a tanteremben, sem a képernyő előtt: a tantermi órák egyszerü rögzítése zsákutca. A hallgatók általában 6-9 perc után leállítják a videókat. Egy másik adatsor szerint a hallgatók fele a 12-15 perces videókból legalább 4,4 percet megnézett (Holmes 2015).

Másrészt a tömeges beiskolázás miatt a MOOC olyan technikai hátteret igényel, amely az interakciók mellett biztosítja a tömeges visszacsatolás, azaz az ellenőrzés vagy a számonkérés eszközét is. Az elmúlt években, köszönhetően innovatív pedagógiai elméleteknek és módszereknek két megközelítés terjedt el:

- a tanuló közösségek által történő önellenőrzés és csoportos együttmüködés

- automatizált visszacsatolás: online tesztek, továbbá komplex írásbeli vizsgák automatizált osztályozása (Rivard 2013)

Az értékelést lehet az online környezetben a legnehezebben megvalósítani: itt a legnehezebb a bizalom megteremtése és fenntartása, továbbá az online értékelési módok meglehetősen eltérnek a klasszikus értékelési metodikától. A MOOC-ban ezért kiemelt figyelmet fordítanak a felügyeletre és az esetleges csalások kiszürésére (Eisenberg 2013)

A csoportos ellenőrzés (más hallgatók által történő ellenőrzés) minta válaszokra vagy feleletválasztós kérdésekre épül, így az ellenőrző érdemben meg tudja ítélni, hogy hány pontot adhat a különböző válaszokra. Megjegyzendö, hogy az értékelési módszerek nem lehetnek annyira sokszínüek a csoportos ellenőrzés esetén, mintha oktatási szakszemélyzet végezné.

Továbbá a csoportos ellenőrzés előnyei között szerepel, hogy azon a hallgatók körében, akik másokat osztályoznak, az osztályozási folyamat tanulással is párosul, továbbá az ellenőrzők a kurzussal kapcsolatban elkötelezettebbé válnak (Adamopoulos 2013). A vizsgák akár felügyelhetők regionális vizsgáztató központokban, vagy egyéb otthoni vizsgakövető technikai eszközök is alkalmazhatók (webkamerák használata, egér használati vagy gépelési szokások, mintázatok algoritmikus felismerése). Az elmúlt időszakban olyan speciális technikák is kidolgozásra kerültek, mint az adaptív (alkalmazkodó) tesztelés, ahol a tesztet a hallgató korábbi válaszai alapján személyre szabják, a hallgató tudásának megfelelő könnyebb vagy nehezebb kérdések megjelenítésének segítségével.

A kurzusok digitalizációja, ezen belül a MOOC és a felsőoktatás hibridizációja az előbbiek alapján egyfajta inflexiós pontként jelenhet meg az oktatás világában. Szabó és szerzőtársai (2019) az Ipar 4.0 és a hálózati tanulás magyarországi kutatása során az első helyen azonosították az emberi erőforrás meglétével és oktatással kapcsolatos kihívásokat, ezen belül a „hagyományos megoldáskezelés” elégtelenségét. Ugyanezen hagyományos, azaz lineáris és termékalapú üzemszervezés helyett javasolja a IT alapú versenyelőnyökben rejlő lehetőségek kihasználását Hortoványi Vilmányi szerzőpáros (2018). Ezek alapján egy tudatos, MOOC alapú digitális transzformációval olyan hibrid felsőoktatási működési modell fejleszthető ki, ami álláspontunk szerint mint az új generációk, mint az intézmények, mint a munkáltatók számára megoldást jelenthetne több közös problémára. Egy MOOC alapú digitális transzformáció az alábbi tényezőkön keresztül fejtheti ki hatását: 
1. táblázat MOOC alapú felsőoktatási müködési modell

\begin{tabular}{lll}
\hline tényező & hatás a felsőoktatásban & $\begin{array}{l}\text { változás mértéke } \\
\text { (kicsi, közepes, magas) }\end{array}$ \\
\hline $\begin{array}{l}\text { kurzus digitalizáció, MOOC } \\
\text { kurzusok fejlesztése }\end{array}$ & $\begin{array}{l}\text { tananyag elemek korlátlan } \\
\text { hozzáférésének megteremtése, } \\
\text { kurzus tartalmának modernizálása készségek }\end{array}$ & $\begin{array}{l}\text { magas: beépíthetők a által elvárt digitális } \\
\text { mukäpiac }\end{array}$
\end{tabular}

MOOC alapú hálózatosodás, stratégiai szövetségek

rugalmasság időben és térben

nyílt forráskódú megközelítés

a piac kiterjesztése

a vevő felhatalmazása a hallgató egyszerre több intézmény kurzusán tud részt venni, a kurzus kínálat a hálózat nagyságától függ magas: eddigi gyakorlat kevés számú szereplő együttműködésére épült

(pl: részképzés, közös diploma)

a kurzusok nem csak a szemesztermagas: az eddig gyakorlat elején kezdődhetnek, és nem csakbeégetett időpontokhoz és egy helyen helyszínekhez közötte a kurzusok kezdetét és helyét

ingyenes csatlakozás: amagas: az eddigi gyakorlat a felhasználó akár kurzusonként,tanulmányok megkezdését a tandíj kreditenként fizethet megfizetéséhez kötötte

6-99 korig

közepes: az eddigi gyakorlat elsősorban a fiatal felnöttekre koncentrált

a diákok nem hallgatók: nem csakkicsi: az eddigi gyakorlat ezt tanártól, egymástól is tanulnak hallgatólagosan elismerte

Forrás: saját szerkesztés

Ezen szempontrendszert figyelembe véve egy MOOC alapú digitális kurzus alkalmas lehet egy új oktatási működési modell kialakítására, ahol a diákok egy hálózat egy csomópontjában, továbbra is campusokon kezdik meg tanulmányaikat, de a hálózat minden eleme nyújt nekik oktatási szolgáltatásokat, és az elvégzett kurzusok a digitális építőkockák a hálózat müködésében, egyben a diplomát jelentő kreditek megszerzésében.

\section{6. Összegzés}

Az egyetemi kurzusok digitális traszformációja a cikkben bemutatott digitális iker felépítése és a MOOC módszertana alapján előkészíthető. Meglátásom szerint egy ilyen hibrid oktatási portfóliónak az egyik bölcsője lehet a klasszikus távoktatás: az Oktatási Hivatal 2015-2019-es adatai alapján készített összegzés azt mutatja, hogy Magyarországon távoktatási tagozatra az elmúlt öt évben stabilan kétezer fö jelentkezett, és ennek fele kezdte meg tanulmányait kevesebb mint öt intézményben. Az adatok alapján a kereslet és a kínálat alakulása stabil. A nem nappali tagozaton 
folyó képzéseknek a bemutatott pár ezer fős távoktatási keresletnél nagyságrendekkel nagyobb potenciálja van egy MOOC alapú képzés transzformáció kapcsán a levelező és esti tagozattal is számolva. Az elmúlt öt év adatai szerint a levelező képzés iránti kereslet 41 ezerről 49 ezerre nőtt, és az esti képzésre beadott jelentkezések is 1566 ról 1803-ra emelkedtek. Mindezt kivetítve egy fenntartható, online oktatási portfólió lehetősége körvonalazódik előttünk, ahol a digitális transzformáció nemzetközi legjobb gyakorlata adaptálható, amihez egy befogadó közeg társulhat a campusok falain kívül is.

\section{Köszönetnyilvánítás}

A kutatást az EFOP-3.6.2-16-2017-00007 azonosító számú, az intelligens, fenntartható és inkluzív társadalom fejlesztésének aspektusai: társadalmi, technológiai, innovációs hálózatok a foglalkoztatásban és a digitális gazdaságban címü projekt támogatta. A projekt az Európai Unió támogatásával, az Európai Szociális Alap és Magyarország költségvetése társfinanszírozásában valósul meg.

\section{Felhasznált irodalom}

Adamopoulos, P. (2013): What Makes a Great MOOC? An Interdisciplinary Analysis of Student Retention in Online Courses. ICIS 2013 Proceedings, pp. 1-21 in AIS Electronic Library (AISeL) http://aisel.aisnet.org/icis2013/proceedings/BreakthroughIdeas/13/

Bloom, B. S. (1984): The 2 Sigma Problem. The Search for Methods of Group Instruction as Effective as One-to-One Tutoring. Educational Researcher, 13, 6. Jun. - Jul., 4-16.

Bowen, W. G. (2014): Higher education in a digital age. Princeton University Press, Princeton.

Brown, M. - Costello, E. - Donlon, E. - Giolla-Mhichil, M. N. (2015): A Strategic Response to MOOCs: How One European University is Approaching the Challenge. International Review of Research in Open and Distributed Learning, 16, 6, 98-115.

Bozkurt, A. - Akgun-Ozbek, E. - Onrat-Yilmazer, S. - Erdogdu, E. - Ucar, H. Guler, E. - Sezgin, S. - Karadeniz, A. - Sen, N. - Goksel-Canbek, N. Dincer, G. D. - Ari, S. - Aydin, C. H. (2015): Trends in Distance Education Research: A Content Analysis of Journals 2009-2013. International Review of Research in Open and Distributed Learning, 16, 1, 330-363. https://www.academia.edu/11056576/Trends_in_Distance_Education_Resear ch_A_Content_Analysis_of_Journals_2009-2013

Eisenberg, A. (2 March 2013): Keeping an Eye on Online Test-Takers. New York Times. Retrieved 19 April 2013.

http://www.nytimes.com/2013/03/03/technology/new-technologies-aim-tofoil-online-course-cheating.html? $\mathrm{r}=1 \&$

Ford, M. (2017): Robotok kora. HVG Kiadó, Budapest. pp 43. 
Holmes, L. (2015): An Early Report Card on Massive Open Online Courses. The Wall Street Journal. Retrieved 3 May 2015. http://www.wsj.com/articles/SB10001424052702303759604579093400834738972

Hortoványi, L. - Vilmányi, M. (2018): Üzletági stratégiák átalakulása a digitalizáció forradalmának forgatagában. In Horváth, D. (szerk.): A stratégiai menedzsment legújabb kihívása: a 4. ipari forradalom c. konferencia kiadvány. Budapesti Corvinus Egyetem, http://unipub.lib.uni-corvinus.hu/3839/1/4ipariforr.pdf

King, A. (2017): Technology: The Future of Agriculture. Nature, 544, S21-S23 https://doi.org/10.1038/544S21a

Matt, C. - Hess, T. - Benlian A. (2015): Digital Transformation Strategies. Business Information System Engineering, 57, 339-343. https://doi.org/10.1007/s12599015-0401-5

Negroponte, N. (1995): Being Digital Hodder and Stoughton. London ISBN 0340 64525 3, 56-66.

Pomerol, J-C. - Epelboin, Y. - Thoury, C. (2015): MOOCs: Design, Use and Business Models. ISTE, London.

Rifkin, J. (1995): The End of Work: the decline of the global labor force and the dawn of the post-market era. G. P. Putnam's Sons; New York, 109-127.

Rivard, R. (19 April 2013): EdX Rejected. Inside Higher Education. Retrieved 22 April 2013. https://www.insidehighered.com/news/2013/04/19/despite-courtshipamherst-decides-shy-away-star-mooc-provider

Skilton, M. - Hovsepian, F. (2018): The 4th Industrial Revolution. p. 6, Palgrave Macmillan, DOI: 10.1007/978-3-319-62479-2

Waldrop, M. M. (13 March 2013): Massive Open Online Courses, aka MOOCs, Transform Higher Education and Science. Nature magazine, Scientific American, Retrieved 28 April 2013. http://www.scientificamerican.com/article/massiveopen-online-courses-transform-higher-education-and-science/

Young, J. R. (2013): The Object Formerly Known as the Textbook. Chronicle of Higher Education, Retrieved 14 March 2013. http://chronicle.com/article/DontCall-Them-Textbooks/136835/

Yousef, A. M. F. - Chatti, M. A. - Schroeder, U. - Wosnitza, M. - Jakobs, H. (April 2014): MOOCs - A Review of the State-of-the-Art. CSEDU International Conference on Computer Supported Education 2014. Barcelona, Spain, 9-20. Retrieved 30 April 2015. http://www.openeducationeuropa.eu/en/article/MOOCs--A-Review-of-the-State-of-the-Art

Szabó, Zs. R. - Horváth, D. - Hortoványi, L. (2019): Hálózati tanulás az ipar 4.0 korában. Közgazdasági Szemle, LXVI, 2019. január, 72-94.

Zemsky, R. (2014): With a MOOC MOOC here and a MOOC MOOC there, here a MOOC, there a MOOC, everywhere a MOOC MOOC. Journal of General Education, 63, 4, 237-243. in JSTOR http://www.jstor.org/stable/10.5325/jgeneeduc.63.4.0237?seq=1\#page_scan_t $\underline{a b}$ contents 